\title{
Governance, Employee Engagement and Improved Productivity in the Public Sector: The Nigerian Experience
}

\author{
Nkogbu Godfrey Oshilim ${ }^{1}$, Offia Patience Akpesiri ${ }^{2}$ \\ ${ }^{1}$ Human Resource/Administration Department, Odogun Nigeria Limited, Warri, Nigeria \\ ${ }^{2}$ Library Department, College of Education, Warri, Delta State, Nigeria \\ Email address: \\ nkogbugodfrey@yahoo.com (N. G. Oshilim),offiap@yahoo.com (O. P. Akpesiri)
}

\section{To cite this article:}

Nkogbu Godfrey Oshilim, Offia Patience Akpesiri. Governance, Employee Engagement and Improved Productivity in the Public Sector: The Nigerian Experience. Journal of Investment and Management. Vol. 4, No. 5, 2015, pp. 141-151. doi: 10.11648/j.jim.20150405.12

\begin{abstract}
This paper examines governance, employee engagement and productivity in the Nigerian public sector. Amidst the high expectations of the citizenry from the new administration of the $6^{\text {th }}$ republic in the Nigerian civilian administration, the reality on ground at the commencement of the new administration in the $6^{\text {th }}$ Republic calls for questions raised by governance in the past administration and consequently employee engagement in the Nigerian public sector as well as its impact on organizational productivity. Owing to the declining level of employee engagement and productivity in the Nigerian public sector, the paper concludes that for productivity to improve in the public sector and for employee engagement to occur, the three Hs (Head, Heart and Hand) of the employee must be effectively engaged in addition to the provision of good governance by government.
\end{abstract}

Keywords: Engagement, Employee Engagement, Governance, Productivity, Public Sector

\section{Introduction}

The clamour for massive "CHANGE" in governance greeted the Nigerian democratic atmosphere during the 2015 electioneering campaigns under the auspices of the All Progressive Congress (APC). This clamour became a reality when on March $28^{\text {th }}, 2015$ the APC's presidential candidate, Muhammadu Buhari emerged victorious at the polls with $15,424,921$ votes $(52.4 \%)$ to defeat Dr. Goodluck Ebele Jonathan of the Peoples Democratic Party (PDP) having $12,853,162$ votes $(43.7 \%)$. This change also saw the APC's candidates winning victories at the gubernatorial, national assembly and states houses of assembly elections. Thus APC became the dominant political party in Nigeria in the $6^{\text {th }}$ republic displacing the Peoples Democratic Party which was the dominant political party in Nigeria during the second to fifth republics.

One might be prompted to ask, why the slogan for 'CHANGE' by the APC? What does the word "CHANGE" means to the uneducated citizens, Nigerians in general and to the party members of APC? Does it mean the entrance of new personalities into the arena of politics and governance? Does it connote the giving of opportunities to the youths to participate in governance? Does it mean the ending of the recycling of old politicians as well as former leaders in the political system of governance? Does it mean the cross carpeting of members from PDP to APC? Or could it be an innovative way towards the governance of the masses? As observers observed, "let's watch what they will do since most of the people in APC were former members of PDP.

In Nigeria, as in most other countries of the world, the attention from citizens has placed more demands on government than ever before (G.O. Nkogbu, 2015). Government's responsibilities as the largest employer of labour and also towards her citizenry is becoming more complex and demanding as a result of the high expectations of the citizenry for quality services amidst the global economic recession characterized by fall in the crude oil prices, and the mono-economy she is operating.

Issues in governance, employee engagement and public sector productivity in the public sector have attracted and is still attracting the attention of all organizational stakeholders in both the public and private sectors. This is as a result of the interaction of the forces of corruption, inappropriate behaviour of political office holders, globalization, advancement in knowledge and technology, the unpredictability of human behavior when given opportunities in the governance of a constitueny, insatiable needs of 
employees, coupled with the constant changes that accompany organizational operations. Within this premise, A. Ighoro (2014) posited that Human Resource (HR) practitioners as well as other relevant organizational stakeholders must position their organizations to stay alive and thus managing employees would require high level of knowledge, deft skills, strategic planning and concerted efforts.

Employee engagement has generated a great deal of interest in recent years as a widely used term in organizations, amongst HR practitioners/consulting firms and recently the academia (W. Macey and B. Scheider, 2008; S. Markos and M.S. Sridevi, 2010). Credible evidence points towards an engagement-profit linkage (C. Coffman, 2000; C. Coffman and G. Gonzalez-Molina, 2002; Hewitt Associates, 2004; R. Heintzman and B. Marson, 2005; M. Czarnowsky, 2008; Right Management, 2009; S. Markos and M.S. Sridevi, 2010; AonHewitt, 2013).

During and after economic disruptions, the way businesses react to economic cycles often predict how well they succeed or they will survive. At such turbulent times and uncertainty, many organizations have been less focused on how to manage their talents and engage their employees, rather they focus on how to reduce costs by cutting salaries, bonuses, rewards and other related employee development costs. Some shortsighted leaders may even think that employee engagement no longer matters because of their need for job security. In the Nigerian scenario, the maxim "a bird in the hand is worth two in the bush" best illustrates this position. However, smart leaders realize that while they need to find short-term solutions to cut costs, they must also identify longer-term talent management strategies to remain viable.

In the past years, Nigerians have been calling for improvement in public service delivery. Pressures for public organizational productivity have been further aggravated by limited resources, wide spread poverty, unemployment, failed infrastructures, high rate of corruption, and high cost of public services, etc. (G.O. Nkogbu, 2015). As noted by various scholars, "an organization cannot perform better than the quality of its workforce" and that "the employees cannot be productive more than the level of knowledge, skills, training, abilities they have".

The dwindling rate of performance in Nigerian public organizations demands some attention to the curious minded people. Of a concern are poor performance, declining productivity, low rate of employee engagement and the behavioural attitude of the bureaucratic system and public/civil servants. Could this be attributed to the maxim, "government's job is no man's job", and "you don't carry government's job on your head but on your shoulder'? This attitude is very obvious in Nigerian public sector organizations.

Despite various government interventions and efforts, the Nigerian public sector score-card has remained a subject of discuss among the academia of public administration and management as well as the curious minded citizens as a result of poor performance and inefficiency in the face of abundant natural and human resources. Reasons given for the massive purge or dismissal of an estimated 10,000 public officers in 1975 were alleged inefficiency, old age, declining productivity, and doubtful probity (A. Adebayo, 2004).

On a sad note, the $6^{\text {th }}$ republic was greeted with obvious failure in governance by the previous administration as the gross financial mismanagement of the Nigerian economy became obvious. Across the federation and in various states, the new administration met little or no funds to commence the conduct of government businesses/functions. What a pitiable situation! Worse still, the previous administration have told the world and Nigerian that the Nigerian economy is booming. What a lie! Profile of Nigerian external debts skyrocketed to the tune of over $\$ 60$ billion. Who is to account for this? Worst still, across the states of the federation, most public and civil servants were being owed several months of salaries. It is within this premise that the new president, Muhammadu Buhari, asserts that "if Nigeria does not kill corruption, corruption will kill Nigeria".

The above scenario calls for leadership accountability and an examination of governance in a democratic dispensation. Closely associated with this is the issue of employee engagement and productivity in the Nigerian public sector. How can one be meaningfully engaged when he/she has not been paid rewards for his/her labour for several months? How can one be productive seeing the gross mismanagement of funds? How can productivity be recorded when the organizational environment is not conducive? This scenario therefore lends credence to the saying by public/civil servants that "government job is no man's job", "don't carry government job on your shoulder", thus implying 'don't be too committed in government's job'.

The effect of governance on employee engagement and productivity in the public sector can be examined from the activities and actions of the political class over a country's public service. In developing countries, political corruption amongst other factors has resulted in declining level of employee engagement as well as decline in productivity in the public service. It is against this background that this paper seeks to examine governance, employee engagement and improved productivity in the public sector in Nigeria.

\section{Operationalization of Concepts}

a) Political Corruption: According to the Encyclopedia Americana (2004), political corruption takes place at the highest levels of political authority. It occurs when the politicians and the political decision-makers, who are entitled to formulate, establish and implement the laws in the name of the people are enriching themselves or further their cause and/or any other person at the expense of the public, in contravention of their oath of office and/or contrary to the laws that are in force. It also takes place when policy formulation and legislation are tailored to benefit politicians and legislators. Political corruption is sometimes similar to the corruption of greed as it affects the shoddy manner 
in which decisions are made, political institutions are manipulated, and rules of procedure are abandoned as well as the distortion and/or destruction of the institutions of government (O.O. Ogunbonna, 2009).

b) Public Sector: Public sector, as a concept, is used to describe the organizations, institutions, and departments of the State which are saddled with the responsibilities and functions of implementing the policies and programmes of government. It is an extension of the executive arm of government, whose personnel perform purely administrative and executive duties (N.P. Ibeme, 2013). In other words, public sector is an organization which is made up of Ministries, Departments and Agencies (MDAs) of government.

c) Public Service: Public service connotes the civil service of the federation and the state as well as the public services of the federation and of the states. It encompasses the federal and state civil services, local government, the Nigeria police, armed forces, judiciary, legislature, educational institutions established or financed mainly by federal and/or state governments, statutory corporations of the federal and state governments, companies or enterprises with full or majority ownership by either the federal or state government. Thus, the public service refers to all organizations that exist as part of government machinery for implementing policy decisions and delivering services that are of value to the citizenry.

The concept of public service as established by the Nigerian Constitution is provided for in sections 169,206 , and 318 and in section 10 of the Third schedule of the 1999 constitution. T. Olaopa (2008) observed that though the constitutional provisions do not recognize the term "The Nigerian Public Service", the constitution only recognizes the Public Service of the Federation at the federal, state and local government levels.

d) Productivity: To Ulrich (1997), as cited in S. Bukar and A. B. Shehu and A. Idris (2012), productivity refers to a ratio of output to input. According to him, input may include labour hours or costs, production costs and equipment costs while output may consist of sales, earnings, and market shares. Productivity means the relationship between output and all factors of production required to achieve it (F. Ojo, 2006). J. Prokopenko (1996) defined productivity as the relationship between the output generated by a production or service system and the input provided to create this output.

According to D. A. Neugarten (1987), productivity is defined from three major perspectives that dominate the field: the economic, the industrial engineering, and the administrative. To the economists, productivity means more yield to the society which must be obtained from present resources and that efficient resource use is therefore paramount. Industrial engineers, on defining productivity, focus on work measurement and performance standards and tend to focus their efforts on those factors which are operational and quantifiable. As per productivity to the administrator, they are more concerned with organizational effectiveness than with the society.

To Menon (1956) as cited in C. Obisi (2005), productivity means an organized mass attack on waste of every type and in every sphere. Thus, it implies development of an attitude of mind and a constant urge to find better, cheaper, quicker, easier and safer ways of doing a job, providing service, and manufacturing an article. It aims at the optimum utilization of the available resources to yielding as many goods and services as possible at the lowest possible cost.

The above views on productivity implies that productivity ranges from efficiency, to effectiveness, to rates of turnover and absenteeism, to output measures, to measures of client or customer satisfaction, to intangibles such as disruption in the workflow and to further intangibles such as morale, loyalty and job satisfaction.

e) Engagement: To D. Zinger (2014), engagement boils down to an employee's passion and commitment to the organization and their job and the drive to deliver the organization's objectives, going the extra mile. According to him, engagement is about emotion, behavior and relationships and that engaged employees have pride in their job and the organization.

Right Management (2009) defined engagement using four definitive factors: commitment to the job and organization; pride in the job and in the organization; willingness to advocate the benefits and advantages of the job and organization; and satisfaction with the job and organization. They concluded that engagement can be described as the degree of employee-organization alignment.

N.P. Rothbard in 2001 described engagement as a psychological presence with two key mechanisms, attention and absorption. Attention is "cognitive ability and the amount of time one spends thinking about a role" and absorption is "being engrossed in a role and refers to the intensity of one's focus on a role" (A.M. Saks, 2006). An engaged employee is a person who is fully involved in, and enthusiastic about, his or her work (G.H. Seijts and D. Crim, 2006). Tim Rutledge in his book "Getting Engaged: The New Workplace Loyalty" explained that truly engaged employees are attracted to, and inspired by, their work ("I want to do this"), committed ("I am dedicated to the success of what I am doing"), and fascinated ("I love what I am doing"). Engaged employees, to him, care about the future of the company and are willing to invest discretionary effort-exceeding duty's call- to see that the organization succeed.

The Royal Bank of Scotland (2005) defined engagement as the state of emotional and intellectual commitment to the group and lists the components as 
satisfaction (how much I like working here), commitment (how much I want to be here) and performance (how much I want to actually do in achieving results).

D. Robinson (2004) defined engagement as a positive attitude held by the employee towards the organization and its values. An engaged employee is aware of business context, and works with colleagues to improve performance within the job for the benefit of the organization. Similarly, W. Kahn (1990) defined engagement as, "the harnessing of organization members' selves to their work roles. In engagement, people employ and express themselves physically, cognitively, and emotionally during role performances."

f) Employee Engagement: Dell Inc. defines employee engagement by stating, "to compete today, companies need to win over the minds (rational commitment) and the hearts (emotional commitment) of employees in ways that lead to extraordinary effort" (R.J. Vance, 2006). The Corporate Leadership Council (2004) defined employee engagement as the extent to which employees commit-both rationally and emotionally- to something or someone in their organization, how they work, and how long they stay as a result of that commitment.

Gallup organization defines employee engagement as the involvement with and enthusiasm for work. They posited that engaged employees are those who "work with a passion and feel a profound connection to their company" and "drive innovation and move the company forward" (GMJ, 2006). Gallup as cited in D. Dernovsek (2008) likens employee engagement to a positive employees' emotional attachment and employee's commitment.

Employee engagement refers to the individual's involvement and satisfaction with as well as enthusiasm for work (J. K. Harter, F.L. Schimdt, and T.L. Hayes, 2002). Employee engagement is a persistent, positive affective-motivational state of fulfillment in employees characterized by high levels of activation and pleasure (C. Maslach, W.B. Schaufeli and M.P. Leiter, 2001). In the same vein, A.M. Saks (2006) conceptualized employee engagement as "a distinct and unique construct that consists of cognitive, emotional and behavioural components that are associated with individual role performance". Commenting on employee engagement, M. Czarnowsky (2008) posited that (engaged) employees are mentally and emotionally invested in their work and in contributing to their employer's success.

K. Shaw (2005) defined employee engagement as "translating employee potential into employee performance and business success and thus "changing the way employees perform by utilizing the tools in the armory of internal communication professionals". According to Shaw, the International Survey research (ISR) refers to engagement as being "a combination of an employee's cognitive (think), affective (feel) and behaviour (act) commitment to a company" and they refer to these constructs-affective, cognitive and behaviour- as making up engagement and not as antecedents or precursors to engagement.

Employee engagement can be considered as cognitive, emotional and behavioural (A.M. Konrad, 2006). Cognitive engagement refers to employees' belief about the company, its leaders and the workplace culture. The emotional aspect of engagement is how employees feel about the company, the leaders and their colleagues. The behavioural aspect of engagement is the valueadded component reflected in the amount of effort employees put into their work-e.g. brainpower, extra time and energy.

g) Governance: The concept of governance connotes the process of managing the affairs of a state. According to the International Encyclopedia of the Social Sciences, governance is the art of exercising of legitimate authority, and protecting and adapting the community by making and carrying out decisions.

h) Government: It is the instrument of the state by which its existence is maintained, its functions carried out and its policies and objectives are realized.

\section{Indicators of Lack of Employee Engagement}

According to G.O. Nkogbu (2015), some indicators of lack or low level of employee engagement include:

1. Lack of interest in work.

2. Carelessness.

3. Wastage of resources and materials.

4. Employees not accepting any responsibility for their work.

5. Decline productivity and profitability.

6. Loss of man-hour/time.

7. High rate of absenteeism.

8. High rate of employee turnover.

9. Employees show up for work, did what they were told to do, and, at the end of their shift, went home, the same routine would be repeated the next day.

10. Missed commitments met with excuses, explanations, rationalizations, and finger-pointing rather than a rigorous and energetic desire to ownership for what went wrong.

11. Employees don't speak up even when they know things are not being dealt with honestly and directly because of fear of cynicism.

12. Problems discussed and debated endlessly, with little lasting improvement from repeated attempts at solution.

13. Initiatives to improve organizational performance progressively slowly or stalling altogether, despite sizeable investments in resources and technology.

14. When people complain about how busy they are 
rather than doing what needs to be done, or complain about the unreasonableness of a leader's expectations. Avoiding rather than taking responsibility.

\section{An Overview of Productivity in the Nigerian Public Sector}

R.R. Nordstrom, T. Lewinson and R.V. Hall (1987) contends that there is a public perception that public employees tend to be complacent and lazy. The questions agitating the minds of most Nigerian scholars, industrialists, leaders in public and private sector organizations as well as the general public about the productivity question include: What is happening? What can we do? How could it be done? Who has to do it? When will it be done?

Nwachukwu (2004) as cited in P.V.C Okoye and R.A. Ezejiofor (2013), identified four major factors of low productivity in the Nigerian public sector. They include:

1. Economic factor: This deals with the reward system of employees in the Nigerian public sector. There is no correlation between efforts spent by an employee and the rewards that he received in the organization. To encourage higher productivity, it is essential that a system of rewards must be designed that attempts to equate hard work and rewards.

2. Sociological factor: This deals with a situation where employees have a sense of belonging in an organization and resist any efforts on the part of management to perceive and treat them only as cost of production.

3. Management factor: He opined that the success or failure of an organization depends solely on the management. An unproductive and undisciplined supervisor can hardly motivate employees. The study conducted shows that in public sector low productivity arises due to managers' unwillingness to manage effectively.

4. Technological factor: This involves the use of new ideas, techniques, innovation, methods and materials to achieve organizational objectives. The lack of proper information to help entrepreneurs select the appropriate technology is one of the major causes of low productivity.

G.O Nkogbu (2015) identified some symptoms of low productivity in the Nigerian public sector to include tardiness, poor quality of service, absenteeism, loss of man-hours during strikes, lots of grievances among public/civil servants, etc.

To deal with problems of low productivity within the country's labour force, there was the establishment of the National Productivity Centre (NPC) in 1987. The aim of setting up this establishment was to tackle the problem of low productivity in the Nigerian economy. It was observed that the NPC established Productivity Improvement Schemes (PIS) in six organizations, comprising the Kaduna Water Board, NIPOST, NITEL, Star Mills, Inlets and West African Portland Cement. The PIS is a mechanism for identifying productivity related problems and developing techniques for solving them, especially for increasing the contributions of human and other resources to productivity.

\subsection{Factors Impeding Productivity in the Nigerian Public Sector}

Under the factors impeding productivity in the Nigerian public sector, G.O. Nkogbu (2015) used the PESTLE model in classifying the factors. PESTLE is a mnemonic where each of the letters stand for different factors affecting organizational productivity in the Nigerian Public Sector.

1. Political factors: This covers the attitudes and actions of legislators, political executives and government officials which affect productivity. It also includes the pressure exerted on the public service by political actors. It is no doubt that public service organizations are very much influenced by politics at the federal, state and local levels. Examples of political factors include retrenchment phenomenon, recruitment methods, and problem of corruption or graft.

2. Economic factors: This factor entails looking out into the organization in terms of the resources which it consumes and the economy outlook. For instance, the fluctuations of the price of crude oil in the international oil market do affect the public service in terms of financial constraints on the government. Economic factors include failure or financial constraints and/or inability to procure needed working materials; tax policy effect, which reduces the take-home pay of workers; high cost of personnel; and none or irregular payment of wages and salaries.

3. Social factors: The social factors is made up of the attitude, desires, expectations, degrees of intelligence and education, beliefs, and customs of people in a given group or society. Social factors also include lack of regard for client convenience; poor attitude of attention to clients/service consumers; attitude of public/service workers towards "tips", "kickbacks", "bribe" for the performance of their legitimate function(s); lack of respect for time; and poverty.

4. Technological factors: It refers to the sum total of knowledge we have of ways to do things. It includes inventions, techniques, etc. Its main influence is on ways of doing things, on how to design, produce, distribute and render services at a greater effectiveness and efficiency. Technological factors further include lack of equipment and working tools; poor maintenance culture of plants, equipment and technical machines; resistance to adoption of innovative ways of doing things, i.e., preference for the status quo.

5. Legal factors: It refers to the laws and regulations of government and the work environment. Example of legal factor includes excessively detailed regulations and procedural routines-bureaucracy.

6. Environmental or ecological factors: It refers to the work environment of organizations and the behaviour of the workers as well as the organization's system. 
Examples of environmental or ecological factors include ineffective management system and method of supervision; poor communication; lack of respect for time; lateness to work; and absenteeism.

\subsection{Improving Productivity in the Public Sector}

According to G.O Nkogbu (2015), improving productivity implies making a commitment to capital investments that might not have immediate payoffs. It also means to increase the ratio of the quality and quantity of services provided to the resources consumed.

Productivity improvement-the production of more and/or better services for each tax naira and man-hour invested- has been an especially attractive strategy for many governments facing tight or shrinking resources (J.M. Greiner, 1992). The fundamental challenge for contemporary public managers is no mystery: how to do more (or almost as much) with less. Productivity is a concern that knows no boundaries. The private sector has productivity problems of its own, too. As B Bozeman (1992) observed, productivity problems can't be solved by alchemy, wizardry or the quick fix. The key to doing more with less lies in how it is done. More effective management can do much to enhance productivity in government and business. Herein lies the impact of human capital as well as its development.

According to D.F. Kettl (1992), public managers are concerned with the development of strategies for efficiently and effectively overseeing their MDAs; build political support, both inside and outside the MDAs; and maintaining of the MDAs health-its organizational capacity and credibility- and obtain needed resources especially funding, personnel, legislation and favourable constituencies.

In furtherance of improving productivity, D.A. Neugarten (2008) and C. Obisi (2005) recommended that the under listed measures should be pursued.

1. Continued research in at least three distinct areas: one is research devoted to developing better indicators of performance-for people, for programmes and for organizations. This implies further development of performance standards and norms, including qualitative measures of performance outcomes. Second is research devoted to examining the implications of increased productivity on the budgetary process. Third is research devoted to the application of behavioural science knowledge to worker productivity.

2. Encouraging and supporting different kinds of demonstration projects and experiments.

3. Heavier capital investments in technology.

4. Establishment of a central information and referral bank.

5. Labour must participate in management.

6. There should be mutual trust and cooperation between employer and employee.

7. Workers should be assured that automation and technology would not displace them.

8. Maintenance of proper communication channel.
9. Proper training and development of workers.

10. Proper equipment be provided and plant maintenance be carried out.

11. Good working conditions and adequate safety measures in the work environment.

Improving productivity in public sector organizations is a shared responsibility among the employees (staff), the general public, elected representatives of the people, and line managers and supervisors (S. Aina, 2005). Thus the stakeholders of productivity in the Nigerian public sector include the public/civil servants (employees/staff of government organizations), political system (elected representatives of the people), organizational management (Chief Executives, Line Managers, Departmental/Divisional Heads, Supervisors), clients/service customers or consumers, and the general public(Civil societies, mass media).

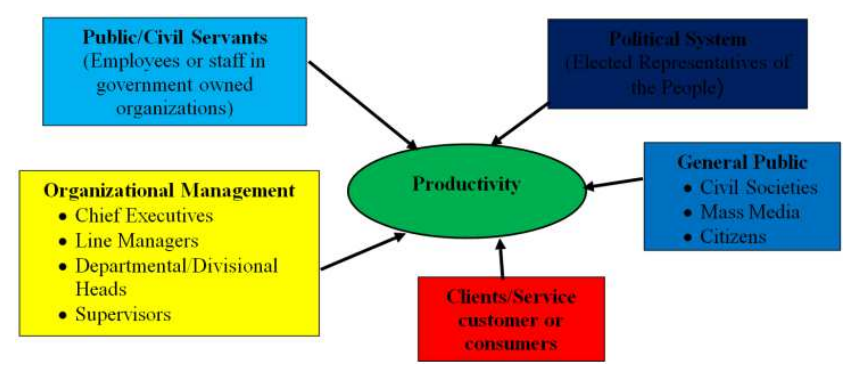

Source: G.O. Nkogbu (2015).

Figure 4.1. Conceptualized Model of Stakeholders of Productivity in the Nigerian Public Sector.

\subsection{Methods of Productivity Improvement Adopted in the Nigerian Public Sector}

In the Nigerian public sector, the under listed methods have been adopted towards improving productivity in different administrations.

1. Downsizing: It entails reductions in size of activity by an organization to boost Return on Investment (ROI) and reduce cost. It may increase the organization's value by reducing the number of employees to increase labour productivity, by closing down or selling off excess of obsolete production establishments.

2. Rightsizing: It entails the process of reducing the number of levels between the least employee and the chief executive in the organization. Its objective is to reduce time lag in decision making, encourage and empower prompt communication and action within the business. Critical path and prompt analysis of each action required to produce the desired result is laid out and the number of people required to do the job is clearly identified and the surplus eliminated.

3. Outsourcing: It is an approach whereby previously internally-produced components are contracted out to external organization/suppliers to allow the firm concentrate its resources, time, and personnel on its core activities. This enables the organization to obtain expert services as and when required without having 
those rendering those skilled services on the payroll of the organization as full time employees.

4. Total Quality Management (TQM): It is a process whereby all employees are made to understand how their roles contribute to the process of production of goods and services.

5. Re-Engineering: It is the radical redesign of a company's business process. It seeks breakthrough not by enhancing existing processes but by discarding them and replacing them with new ones.

6. Technology Improvement.

\section{Governance and Accountability in Nigeria}

There is a general opinion that most of the public enterprises have failed to deliver on the purposes for which they were established. Political corruption, management ineffectiveness and inefficiency, low level of employee engagement have been advanced by practitioners and researchers as the bane of the Nigerian public sector (G.O.Nkogbu, 2015). The former president of Nigeria, Olusegun Obasanjo (2003) observed that:

Nigerians have too long been feeling short-changed by the quality of public service. Our public offices have too long been showcases for combined evils of inefficiency and corruption, whilst being impediments for effective implementation of government policies. Nigerians deserve better and we will ensure they get what is better.

In a similar vein, Agagu (2008) asserts that:

The public service which was seen as the custodian of rules and regulations and the engine of development had lost its prestige and confidence. The aftermath of this is the invention of series of reforms which, have led to privatization, downsizing and right-sizing of the public service and even minimizing the role of the public sector in the national life.

Nigeria, the 6th largest oil producing nation of the world, with a population of over 170 million is richly endowed with all kinds of natural and human resources. Yet, the standard of living of most Nigerians has left much to be desired of governance. This show that there is a missing link between governance, the government and the governed. The Human Development report of 2013 does not tell well of Nigeria as a nation. In this report, Nigeria is ranked 153rd out of 186 countries and is categorized under low development countries; $17.8 \%$ of Nigerian population is vulnerable to poverty; $33.9 \%$ of her population is in severe poverty; $54.7 \%$ of Nigerians live below the national poverty line; and $68 \%$ of Nigerians live below $\$ 1.25$ a day under the multidimensional poverty index (HDR, 2013).

The need for accountability in governance and the increasing government involvement in various economic ventures in the economy makes accountability by political and public office holders necessary if one is to avoid a repeat of Mobutu, Ferdinand or General Sani Abacha type of government of plundering the treasury and impoverishing the poor.

Accountability for actions by public office holders was made insistent in the political and economic history of developed countries. According to O.O. Ogunbona (2009), only a few African heads of government like Leopold Senghor of Senegal, Kwame Nkrumah of Ghana, Julius Nyerere of Tanzania and Chief Obafemi Awolowo of Nigeria were up to the responsibility of being accountable to the public both in the use of power and government funds.

\section{Kinds of Accountability}

Mandatory Accountability: This is a type of accountability where constitutional, conventional or legal provisions and measures are put in place to ensure that those exercising authority over the use of public resources are made to answer to the people's wishes, failing, which the people, if they so desire can remove them from office.

Discretionary Accountability: This type of accountability also known as voluntary accountability exist where those who exercise political as well as administrative power take action based on the people's wishes in accordance with political ideological commitments or on grounds of morality rather than on grounds of law or constitutionalism or as a result of scale of preference determined by the people in a democratic manner. A. Sen (2004) referred to "the commitment to ideology which extracts a minimum standard of behaviour and performance from the government" as "political commitment of the system". According to him, a typical example is the response of the Chinese and Indian governments toward the issues of hunger and famine.

In Nigeria, the depth and severity of non-accountability and non-transparency in governance was heightened during the $5^{\text {th }}$ republic. It was more evident as it was experienced across the local, states and federal governments. This situation makes it very uneasy for the new administration in the $6^{\text {th }}$ republic to take-off effectively as the previous administration according to reports emptied the treasury of federal and state governments thus making little or no funds for the new administration to commence business successfully. Furthermore, the issues of federal and state governments owing several months of salaries of public and civil servants makes it very challenging. Worse still, this scenario have an impact on employee engagement.

Below is a table showing the debt profile of states of Nigeria as at April, 2015.

Table 5.1. Table showing debt profile of states in Nigeria.

\begin{tabular}{llll}
\hline \multicolumn{4}{l}{ South-East Geo-Political Zone } \\
\hline \multirow{2}{*}{ /N } & STATES & $\begin{array}{l}\text { DEBT } \\
\text { ( \$Million) }\end{array}$ & DEBT (in NBillion) \\
\hline 1 & Abia & 33,791 & 6,758 \\
2 & Anambra & 45,155 & 9,031 \\
3 & Ebonyi & 45,411 & 9,082 \\
4 & Enugu & 68,929 & 13,786 \\
5 & Imo & 52,950 & 10,590 \\
& TOTAL & 246,235 & 49,247 \\
\hline
\end{tabular}




\begin{tabular}{|c|c|c|c|}
\hline \multicolumn{4}{|c|}{ South-South Geo-Political Zone } \\
\hline $\mathrm{S} / \mathrm{N}$ & STATES & DEBT ( \$Million) & DEBT (in NBillion) \\
\hline 1 & Akwa Ibom & 58,887 & 11,777 \\
\hline 2 & Bayelsa & 34,832 & 6,966 \\
\hline 3 & Cross River & 141,470 & 28,294 \\
\hline 4 & Delta & 24,234 & 4,847 \\
\hline 5 & Edo & 123,128 & 24,626 \\
\hline \multirow[t]{2}{*}{6} & Rivers & 44,725 & 8,945 \\
\hline & TOTAL & 427,276 & 85,455 \\
\hline \multicolumn{4}{|c|}{ South-West Geo-Political Zone } \\
\hline $\mathrm{S} / \mathrm{N}$ & STATES & DEBT ( \$Million) & DEBT (in NBillion) \\
\hline 1 & Ekiti & 46,453 & 9,291 \\
\hline 2 & Lagos & $1,169,713$ & 233,943 \\
\hline 3 & Ogun & 109,155 & 21,831 \\
\hline 4 & Ondo & 52,689 & 10,538 \\
\hline \multirow[t]{3}{*}{5} & Osun & 74,053 & 14,811 \\
\hline & Оуо & 72,351 & 14,470 \\
\hline & TOTAL & $1,524,413$ & 304,883 \\
\hline \multicolumn{4}{|c|}{ North-Central Geo-Political Zone } \\
\hline $\mathrm{S} / \mathrm{N}$ & STATES & DEBT ( \$Million) & DEBT (in NBillion) \\
\hline 1 & Benue & 33,074 & 6,615 \\
\hline 2 & FCT & 36,636 & 7,327 \\
\hline 3 & Kogi & 35,788 & 7,158 \\
\hline 4 & Kwara & 52,722 & 10,544 \\
\hline 5 & Nassarawa & 49,943 & 9,989 \\
\hline 6 & Niger & 44,750 & 8,950 \\
\hline \multirow[t]{2}{*}{7} & Plateau & 30,948 & 6,190 \\
\hline & TOTAL & 283,861 & 56,772 \\
\hline \multicolumn{4}{|c|}{ North-East Geo-Political Zone } \\
\hline $\mathrm{S} / \mathrm{N}$ & STATES & DEBT ( \$Million) & DEBT (in NBillion) \\
\hline 1 & Adamawa & 46,775 & 9,355 \\
\hline 2 & Bauchi & 87,572 & 17,514 \\
\hline 3 & Borno & 23,068 & 4,614 \\
\hline 4 & Gombe & 39,546 & 7,909 \\
\hline 5 & Taraba & 22,780 & 4,556 \\
\hline \multirow[t]{2}{*}{6} & Yobe & 31,238 & 6,248 \\
\hline & TOTAL & 250,978 & 50,196 \\
\hline \multicolumn{4}{|c|}{ North-West Geo-Political Zone } \\
\hline \multirow[t]{2}{*}{$\mathrm{S} / \mathrm{N}$} & STATES & DEBT ( \$Million) & DEBT (in NBillion) \\
\hline & Jigawa & 35,718 & 7,144 \\
\hline 2 & Kaduna & 234,416 & 46,883 \\
\hline 3 & Kano & 59,797 & 11,959 \\
\hline 4 & Katsina & 78,925 & 15,785 \\
\hline 5 & Kebbi & 43,786 & 8,757 \\
\hline 6 & Sokoto & 44,865 & 8,973 \\
\hline \multirow[t]{2}{*}{7} & Zamfara & 35,548 & 7,110 \\
\hline & TOTAL & 533,054 & 106,611 \\
\hline
\end{tabular}

Source: C. Ndujihe (April 18, 2015).

As at December, 2014 according to the Debt Management Office, Nigeria's total public debt stock was $\$ 67.73$ billion and $\$ 11.24$ trillion (C. Ndujihe, 2015). The implication of the above information is that all is not well with governance in Nigeria from the financial management perspective. This effect transcended into public sector organizations resulting in the salary arrears being owed public/civil servants across the country. This is an abnormality given the resources coming into the nation's treasury. At this juncture, the curious minded stakeholder in Nigerian governance might be prompted to ask certain questions: what is happening to the management of the nation's financial resources? Can this high debt profile be justified given the high level of unemployment, inequality, poverty, low level of standard of living of the average
Nigerian? What should the new administration do about this situation? Shouldn't the political office holders in the $5^{\text {th }}$ republic be arraigned before the nation and the various states to give justifiable account for these debts? What is the impact of the acclaimed reasons for these debts in the various states that these monies were alleged to have been spent on? The irony of the situation is that these political office holders has amassed wealth at the expense of Nigerians. Will they (ex-political and public office holders in the $5^{\text {th }}$ republic) go free? Will it be business as usual in this $6^{\text {th }}$ republic? Only time will tell.

Often times, these "class of political holders" are regarded as sacred cows and in most time go free as if nothing had happened as it used to in time past. What an impunity in governance! In Delta State for instance, it was observed that the state is financially broke as the state's treasury was in red (empty) hence the new administration have to source for funds to get government running in the midst of huge debt left behind for the incoming administration in the $6^{\text {th }}$ Republic.

\section{Employee Engagement and Organizational Performance}

Questions that often arise in the minds of practitioners, scholars, and other organizational stakeholders is, why should organizations should be concerned with employee engagement? The answer is that organizational stakeholders should be concerned because employee engagement impacts organization's performance as well as organizational outcomes. Studies have found positive relationship between employee engagement and organizational performance outcomes: employee retention, productivity, profitability, customer loyalty and safety. Researches also indicate that the more engaged employees are, the more likely their employer is to exceed the industry average in its revenue growth. Employee engagement is found to be higher in double-digit growth companies. Research also indicates that engagement is positively related to customer satisfaction (C. Coffman, 2000; C. Coffman and G. Gonzalez-Molina, 2002; Towers Perrin Talent Report, 2003; Hewitt Associates, 2004; R. Heintzman and B. Marson, 2005; C.M. Ellis and A. Sorensen, 2007).

Research has consistently shown that employee engagement is powerfully linked to a range of business success factors such as employee performance/efficiency (J.K. Harter, F.L. Schmidt and T.L. Hayes, 2002; L. Holbeche and N. Springett, 2003;), productivity (C. Maslach, W.B. Schaufeli and M.P. Leiter, 2001), safety (W. Kahn, 1990; D. R. May, R.L. Gilson and L.M. Harter, 2004; Vance, 2006), attendance and retention (L. Holbeche and N. Springett, 2003; W.B. Schaufeli, A. Bakker and M. Salanova, 2006), customer service and satisfaction (D.R. Roberts and T.O. Davenport, 2002), profitability (G.H Seiijts and D. Crim, 2006; R.J. Vance, 2006), health (S. 


\section{Crabtree, 2005).}

For example, at the beverage company of Molson Coors, it was found that engaged employees were five times less likely than nonengaged employees to have a safety incident and seven times less likely to have a lost-time safety incident. In fact, the average cost of a safety incident for an engaged employee was $\$ 63$, compared with an average of $\$ 392$ for a nonengaged employee. Consequently, through strengthening employee engagement, the company saved $\$ 1,721,760$ in safety costs in 2002. In addition, savings were found in sales performance teams through engagement In 2005, for example, low-engagement teams were seen falling behind engaged teams, with a difference in performance-related costs of low- versus high-engagement teams totaling \$2,104,823.9 (R.J. Vance, 2006).

Right Management (2009) posited that employee engagement is, arguably, the most critical metric for organizations in the twenty-first century. Most, if not all, other key measures that reflect and drive organizational performance (customer satisfaction, innovation, profitability, productivity, loyalty and quality) are products of engaged, committed employees. Their findings revealed that there is a strong relationship between the level of employee engagement and organizational performance as employee engagement is powerfully linked to a range of business success factors. Their survey of engagement of 28,810 employees from a broad range of industry sector from 15 countries in America, Europe, and Asia-Pacific confirmed that engagement leads to higher financial performance, higher customer satisfaction and higher employee retention, increased productivity, and profitability.

According to the Gallup research, organizations with high levels of engagement routinely outperform their competitors; they are $27 \%$ more profitable, they have $38 \%$ above average productivity, and have 50\% higher customer loyalty. In a similar vein, the CLC (2004) in their survey of more than 50,000 employees of 59 global organizations found out that those employees who are most committed perform $20 \%$ better and are $87 \%$ less likely to leave the organization-indicating the significance of engagement to organizational performance.

Similarly, Stephen Young, the Executive Director of Towers Perrin, contended that only engagement (not satisfaction) is the strongest predictor of organizational performance (Human Resources, 2007).

Arising from the above, what will happen to an organization if its employees are disengaged? Employees who are not engaged are likely to be spinning (wasting their effort and talent on tasks that may not matter much), settling (certainly do not show full commitment, not dissatisfied enough to make a break) and splitting (they are not sticking around for things to change in their organization), have far more misgivings about their organization in terms of performance measures such as customer satisfaction (Blessing White, 2006; Perrin Report, 2003). M. Meere (2005) based on the survey conducted by ISR on 360,000 employees from 41 companies in the world's 10 economically strong countries found out that both operating margin and net profit margins reduced over a three year period in companies with low engagement, while these measures increased over the specified period in companies with high levels of engagement. Financial News, March 2001, as cited by Accord Management Systems (2004), reveals that disengaged employees are more likely to cost their organization. According to the report, employees who are disengaged miss an average of 3.5 more days per year; are less productive and cost the US economy $\$ 292$ to $\$ 355$ billion per year.

\section{Conclusion}

Productivity in the Nigerian public sector is dependent on employee engagement and governance. Put differently, without employee engagement and good governance there cannot be improved productivity. The system of governance in any given country provides the framework for organizational practices which to a great extent contributes to the level of employee engagement inter alia the determination of productivity level. Without a workplace environment for employee engagement, employee turnover will increase and efficiency will decline, thus leading to decline in organizational performance.

Having a holistic knowledge of employee engagement can be helpful in determining what is working and what is not. This will offer organizational leaders and HR practitioners a way to better understand what practices and policies in their organization effectively promote employee motivation, productivity and retention.

This paper therefore concludes that for productivity to improve in the public sector and for employee engagement to occur, the three Hs (Head, Heart and Hand) of the employee must be effectively engaged in addition to the provision of good governance by government.

\section{Recommendation}

Due to the strategic importance of public sector organizations in delivering the dividends of democracy and good governance, the following recommendations are made with a view to improving productivity in public sector organizations.

1. Employee engagement should be the concern of all stakeholders of productivity.

2. Engagement of employees should be complemented by the provision of opportunities and creation of a conducive environment for the employees to express their talents, creativity, initiatives and newly acquired skills, knowledge, experience, exposure and abilities.

3. Provision of resources for performance of job functions, training, learning and development opportunities, and establishment of a good and fair reward system is very vital in the improvement of productivity in public sector organizations.

4. Those saddled with the opportunity and responsibility 
of governance should justify the people's trust on them and must be held accountable.

\section{References}

[1] G.O. Nkogbu. "Impact of Human Capital Development on Organizational Productivity in the Nigerian Public Sector: A Case Study of Nigerian Ports Authority (Delta Ports, Warri)". Unpublished M.Sc Dissertation. Lagos: National Open University of Nigeria, 2015.

[2] A. Ighoro. "Expanding the Frontiers of Human Resource Practice". HR Newsletter of Chartered Institute of Personnel Management of Nigeria, Delta State Branch, Vol., No. 3, pp. 2, 2014.

[3] W. Macey and B. Schenider. "The Meaning of Employee Engagement". Industrial and Organizational Psychology, Vol.1, pp. 3-30, 2008.

[4] S. Markos and M.S. Sridevi. "Employee Engagement: The Key to Improving Performance". International Journal of Business and Management, Vol. 5, No.12, pp. 89-96, 2010.

[5] C. Coffman. "Is Your Company Bleeding Talent? How to become a true "employer of choice". The Gallup Management Journal, 2000.

[6] C. Coffman and G. Gonzalez-Molina. "Follow this Path: How the World's Greatest Organizations Drive Growth by Unleashing Human Potential". New York: Warner Books, Inc., 2002.

[7] Hewitt Associates. "Employee Engagement Higher at Double Digit Growth Companies". Research Brief, Hewitt associates LLC, 2004.

[8] R. Heintzman and B. Marson, "People, Service and Trust: Links in a Public Sector Service Value Chain". International Review of Administrative Studies, Vol.7, No.4, pp. 549-575. December, 2005.

[9] M. Czarnowsky. "Learning's Role in Employee Engagement: An ASTD Research Study". Alexandria, VA: ASTD, 2008.

[10] Right Management. Employee Engagement: Maximizing Organizational Performance, 2009

[11] S. Markos and M.S. Sridevi. "Employee Engagement: The Key to Improving Performance". International Journal of Business and Management, Vol. 5, No. 12, pp. 89-96, 2010.

[12] Aon Hewitt. "Trends in Global Employee Engagement" In www.aonhewitt.com \{Online: Accessed January 5, 2015\}.

[13] A. Adebayo. "Principles and Practice of Public Administration in Nigeria". Ibadan: Spectrum Books Limited, 2004.

[14] N.P. Ibeme. "Ecology of Public Administration". Lagos: National Open University of Nigeria, 2013.

[15] T. Olaopa. "Theory and Practice of Public and Civil Service Reforms in Nigeria”. Ibadan: Spectrum Books Limited, 2008.

[16] S. Bukar, A.B. Shehu, and A. Idris. "The Effect of Human Resource Management on Productivity of Workers in Nigeria", Journal of Business and Organizational Development, Vol. 4, pp.59, 2012.

[17] F. Ojo. "Personnel Management: Theories and Issues". Lagos:
Allied Emant Company, 2006.

[18] J. Prokepenko. "Productivity Management: A Practical Handbook". Quarterly Journal of Economics, Vol. 45, No.57, pp. 407-443, 1996.

[19] D.A. Neugarten. "Themes and Issues in Public Sector Productivity". Public Personnel Management Journal, pp. 229-235, 1987.

[20] C. Obisi, C. "Substance of Employee, Industrial and Labour Relations". Lagos: Megavons (West Africa) Limited, 2005.

[21] D. Zinger. "The History of Employee Engagement". In www.davidzinger.com \{online: Accessed December 20, 2014\}

[22] A.M. Saks. "Antecedents and Consequences of Employee Engagement". Journal of Managerial Psychology, Vol. 21, pp.600-619, 2006.

[23] G.H. Seijts and D.Crim. "What Engages Employees the Most, or the Ten C's of Employee Engagement". Ivey Business Journal, March/April, 1-5, 2006.

[24] W. Kahn. "Psychological Conditions of Personal Engagement and Disengagement at Work". Academy of Management Journal, Vol. 33, No. 4, pp. 692-724, 1990.

[25] R.J. Vance. "Effective Practice Guidelines: Employee Engagement and Commitment". Alexandria, VA: SHRM Foundation, 2006.

[26] Corporate Leadership Council. "Driving Performance and Retention through Employee Engagement". Washington, DC: Corporate Executive Board, 2004.

[27] D. Dernovsek. "Creating Highly Engaged and Committed Employee Starts at the Top and Ends at the Bottom Line". Credit Union Magazine, May 2008. Credit Union National Association, Inc.

[28] J.K. Harter, F.L. Schmidt and T.L. Hayes. "Business-UnitLevel Relationship between Employee Satisfaction, Employee Engagement, and Business Outcomes: A Meta-Analysis". Journal of Applied Psychology, Vol.8, pp. 268-279, 2009.

[29] C. Maslach, W.B. Schaufeli and M.P. Leiter. "Job Burnout". Annual Review of Psychology, Vol.52, pp. 397-422, 2001.

[30] K. Shaw. "Employee Engagement, How to Build a HighPerformance Workforce". Melcrum Publishing Limited, 2005.

[31] A.M. Konrad. "Engaging Employees through High Involvement Work Practices". Ivey business Journal Online: www.iveybusinessjournals.com \{Online: Accessed January 5, $2015\}$.

[32] R.R. Nordstrom, T. Lewinsohn, and R.V. Hall. "Productivity in the Public Sector: A Discussion of the Issues". Public Personnel Management Journal, Vol. 16, No. 1, pp. 1-8., 1987.

[33] P.V.C. Okoye, and R.A. Ezejiofor, R.A. "The Effect of Human Resources Development on Organizational Productivity". International Journal of Applied Research in Business and Social Sciences, Vol. 3, No. 10, pp. 250-268,2013.

[34] J.M. Greiner. "Motivational Programs and Productivity Improvement in Times of Limited Resources". In R.B. Denhardt and B.R. Hammond "Public Administration in Action: Readings, Profiles and Cases". California: Brooks/Cole Publishing Company, 1992. 
[35] B. Bozeman. "Strategic Public Management and Productivity: A "Firehouse Theory". In R.B. Denhardt and B.R. Hammond "Public Administration in Action: Readings, Profiles and Cases”. California: Brooks/Cole Publishing Company, pp. 332, 1992.

[36] D. F. Kettl. "The Perils and Prospects of Public Administration". In R.B. Denhardt and B.R. Hammond "Public Administration in Action: Readings, Profiles and Cases". California: Brooks/Cole Publishing Company, pp. 15, 1992.

[37] S. Aina. "Managing the Human Capital in Nigeria". Lagos: Fountain Training Consult, pp.30, 2005.

[38] Human Development Report. "The Rise of the South: Human Progress in a Diverse World". Basingstoke, Hampshire: Palgrave Macmillan Houndmills, 2013.

[39] O.O. Ogunbonna. "Analysis of Non-Accountability in Nigeria". Human Resource Management Journal, Vol.1, No.2, pp. 26-38, 2009

[40] A. Sen, A. "Development: Which Way Now?" The Economic Journal, pp.757. December, 2004.

[41] C. Ndujihe. "Huge Debts Await Buhari, In-Coming Governors",2015 In www.vanguardngr.com \{Online: Accessed 24th June, 2015\}

[42] Towers Perrin. "Winning Wtrategies for a Global Workforce". Retrieved October 25, 2006, from www.towersperrin.com.
[43] C.M. Ellis and A. Sorensen. "Assessing Employee Engagement: The Key to Improving Productivity". Perspectives, Vol.1, No. 15, 2007. The Segal Group, Inc.

[44] L. Holbeche and N. Springett. "In Search of Meaning in the Workplace”. Horsham: Roffey Park, 2003.

[45] D.R. May, R.L. Gilson and L.M. Harter. "The Psychological Conditions of Meaningfulness, Safety and Availability and the Engagement of the Human Spirit at Work". Journal of Occupational and Organizational Psychology, Vol.77, pp.1137, 2004.

[46] W.B. Schaufeli, A. Bakker and M. Salanova. "The Measurement of Work Engagement with a Short Questionnaire: A Cross-National Study". Educational and Psychological Measurement, Vol. 66, pp. 701-716, 2006.

[47] D.R. Roberts and T.O. Davenport. "Job Engagement: Why It's Important and How to Improve It". Wiley Periodicals, Inc, pp. 21-29, 2002.

[48] S. Crabtree. "Engagement Keeps the Doctor Away". Gallup Management Journal, 2005 in http:gmj.gallup.com

[49] M. Meere. "High Cost of Disengaged Employees", 2005. Victoria: Swinburne University of Technology. [Online] Available:

http://www.swinburne.edu.au/corporate/industrysolutions/ee/r eports/Employee\%20Engagement\%20industry\%20Breifing\% 20Paper\%20Dec\%202005\%20.pdf (October 30, 2008). 